\title{
Milk Yield and Nutrient Adequacy of Lactating Dairy Cow Fed Based on Tofu Waste, Soybean Hulls and Straw
}

\author{
Nur Santy Asminaya ${ }^{1}$, Bagus P Purwanto ${ }^{2}$, Nahrowi $^{3}$, Wonny A Ridwan ${ }^{4}$, Afton Atabany ${ }^{5}$ \\ ${ }^{1}$ Bogor Agricultural University, Departement of Animal Production and Technology, Agatis Road, Dramaga Campus 16680, Indonesia \\ ${ }^{2}$ Vocational college, Bogor Agricultural University, Kumbang Road No 14, Indonesia \\ ${ }^{3}$ Bogor Agricultural University, Department of Animal Nutrition and Feed technology,Agatis Road, Dramaga Campus 16680, Indonesia \\ ${ }^{4}$ Vocational college, Bogor Agricultural University, Kumbang Road No 14, Indonesia
}

${ }^{5}$ Bogor Agricultural University, Departement of Animal Production and Technology, Agatis Road, Dramaga Campus 16680, Indonesia

\begin{abstract}
This study was done to assess the adequacy of nutrient intake and feed efficiency in dairy cows using agricultural byproducts as feedstuff. Treatments of feed in this study refered to the pattern of feed given by farmers with different feed ingredients formula i.e (T1, $21.42 \%$ tofu waste; T2, $19.00 \%$ tofu waste; T3, 38.18\% tofu waste $+16.50 \%$ soybean hulls $+8.86 \%$ straw; T4, 32.71\% tofu waste $+23.10 \%$ straw; T5, $25.20 \%$ tofu waste $+5.96 \%$ soybean hulls; T6, $9.13 \%$ tofu waste $+32.80 \%$ straw; T7, $21.99 \%$ tofu waste $+28.58 \%$ straw; and T8, 30.52 soybean hulls). The variables measured were dry matter intake (DMI), crude protein intake (CPI), total digestible nutrients (TDN), milk production, milk composition and feed efficiency. Data were analyzed using t-test as independent samples. DMI did not met the requirement of dairy cows except for cows received $\mathrm{T} 4$ and $\mathrm{T3}$, while the protein requirements of cows met except for cows received $T 7$ while TDN requirement only met for cows received T3, T5 and T6. The highest milk yield was for cows received T8. It can be concluded that the pattern of feeding in Cibungbulang smallholder dairy farm varied so the milk yield also varies and T3 showed the best feed formula.
\end{abstract}

Keywords: Feed efficiency, agricultural waste, milk production, smallholder dairy farm

\section{Introduction}

Frisien Holstein (FH) is the largest milk producer in Indonesia, but the amount of dairy products can not meet national needs so there was a wide gap between milk production and consumption. This is caused by the production of milk mostly comes from smallholder dairy farm in Central, East and West Java. This situation affects milk requirement and consumption in Indonesia is lower than others countries even within the Southeast Asian countries.

Low levels of milk yield is generally caused by several factors, including genetic [1], environment, lactation periode, months of lactation, days open [2], meeting the needs of feed, feed quality [3] and the availability of feed. On dairy farm, the pattern of feeding quite varied in combination i.e napier grass and concentrate [4], king grass, concentrates (bran, corn meal, coconut, pollard, cassava) and tofu [2], corn silage, grass and tofu [5], napier grass, field grass, corn silage, waste of cassava, soybean and coconut [6], napier grass, concentrate and rice bran [7]. Varied of feeding patterns causes milk production also varies. Milk production ranged from 8.37-18.66 L/day [8, 9, 10, 5]. Therefore, for optimal milk production and increase farmer income, it was needed information on feeding quality information, available in sufficient quantities with low cost but fullfill the stock requirement. This study was done to assess the adequacy of nutrient intake and feed efficiency in dairy cattle using agricultural byproducts as feedstuff.

\section{Materials and Methods}

\subsection{Time and place}

The research was conducted in the rainy season (JuneOktober 2015) on smallholder dairy farm in Cibungbulang, West Java. Analysis of feed samples were carried out on Science and Feed Technology Laboratory, and milk samples were carried out on Laboratory of Livestock Production and Technology, Faculty of Animal Husbandry, Bogor Agricultural University.

\subsection{Experimental Design}

This study used 72 FH lactation dairy cows. Treatment of feed in this study consisted of : T1, $21.42 \%$ tofu waste; T2, $19.00 \%$ tofu waste; T3, $38.18 \%$ tofu waste $+16.50 \%$ soybean hulls $+8.86 \%$ straw; $\mathrm{T} 4,32.71 \%$ tofu waste + $23.10 \%$ straw; $\mathrm{T} 5,25.20 \%$ tofu waste $+5.96 \%$ soybean hulls; T6, 9.13\% tofu waste $+32.80 \%$ straw; T7, $21.99 \%$ tofu waste $+28.58 \%$ straw; and $\mathrm{T} 8,30.52$ soybean hulls.

Formula feeding treatment (Table 1) were used in this study refered to the pattern of given by farmers in Cibungbulang smallholder dairy farm. Feed samples in each treatment were analyzed using proximate analysis [11] with a nutrient content results were shown Table 2. 


\section{International Journal of Science and Research (IJSR) \\ ISSN (Online): 2319-7064}

Index Copernicus Value (2015): 78.96 | Impact Factor (2015): 6.391

Table 1: Formula Feeding Treatment (\%) on Cibungbulang Smallholder Dairy Farm

\begin{tabular}{|c|c|c|c|c|c|c|c|c|}
\hline $\begin{array}{c}\text { Feed Formula } \\
(\%)\end{array}$ & T1 & T2 & T3 & T4 & T5 & T6 & T7 & T8 \\
\hline Napier grass & 36,70 & 62,28 & 15,27 & 17,05 & 32,77 & 0,00 & 32,15 & 30,41 \\
\hline Field grass & 13,00 & 1,87 & 1,14 & 0,69 & 4,14 & 15,99 & 0,88 & 1,75 \\
\hline concentrate & 28,88 & 16,85 & 20,05 & 26,46 & 31,92 & 19,84 & 16,41 & 37,32 \\
\hline Tofu waste & 21,42 & 19,00 & 38,18 & 32,71 & 25,20 & 43,92 & 21,99 & 0,00 \\
\hline Soybean hulls & 0,00 & 0,00 & 16,50 & 0,00 & 5,96 & 0,00 & 0,00 & 30,52 \\
\hline Straw & 0,00 & 0,00 & 8,86 & 23,10 & 0,00 & 20,24 & 28,58 & 0,00 \\
\hline
\end{tabular}

Table 2 : Nutrient Content of Each Treatmeant (\% DM) on Cibungbulang Smallholder Dairy Farm

\begin{tabular}{|c|c|c|c|c|c|c|c|}
\hline Treatment & DM & Ash & CP & CF & EE & BeTN & TDN \\
\hline T1 & 16,31 & 10,50 & 17,87 & 28,51 & 3,66 & 39,46 & 74.44 \\
\hline T2 & 18,02 & 10,95 & 14,93 & 29,38 & 3,61 & 41,14 & 71.41 \\
\hline T3 & 16,54 & 6,26 & 19,90 & 27,30 & 7,07 & 39,46 & 71.89 \\
\hline T4 & 20,86 & 8,39 & 18,80 & 26,80 & 5,87 & 40,14 & 74.21 \\
\hline T5 & 17,65 & 7,31 & 15,80 & 32,68 & 2,82 & 41,38 & 71.59 \\
\hline T6 & 17,72 & 8,51 & 16,65 & 29,95 & 4,47 & 40,42 & 74.01 \\
\hline T7 & 17,34 & 9,82 & 15,92 & 27,49 & 3,02 & 43,75 & 76.71 \\
\hline T8 & 20,48 & 10,26 & 14,20 & 36,91 & 1,03 & 37,60 & 69.08 \\
\hline
\end{tabular}

Source : Proximate analysis were carried out on Science and Feed Technology Laboratory

$\mathrm{DM}=$ Dry matter $; \mathrm{CP}=$ Crude protein $\mathrm{CF}=$ Crude fiber; $\mathrm{EE}=$ Estract eter;

TDN $=$ Total digestible nutrien; $\%$ TDN $=92.464-3.338(\mathrm{CF})-$ $6.945(\mathrm{EE})-0.762(\mathrm{BeTN})+1.115(\mathrm{P})+0.031(\mathrm{CF})^{2}-0.133(\mathrm{EE})^{2}+$ $0.036(\mathrm{CF})(\mathrm{BeTN})+0.207(\mathrm{EE})(\mathrm{BeTN})+0.100(\mathrm{EE})(\mathrm{P})-0.022$ $(\mathrm{EE})^{2}(\mathrm{P})$ (Hartadi et al. 1986);

Forage were given ad libitum every day. Feeding were done in the morning (at 06:00 to 08:00 am) and afternoon (04:00 to $05: 30 \mathrm{pm}$ ). The residual of the feed given was calculated by weighing feed which unconsumed by cattle in the next day. The difference between the feed given and the residual feed for 24 hours was recorded as a daily feed intake.

Adequate intake of nutrients was calculated by counting the dry matter intake, crude protein intake, total digestible nutrien and then compared to the nutrient requirement of lactating dairy cows based on Nutrient Requirements of Ruminants in Developing Countries (NRRDC) [12].

Measurements of milk yield were done in the morning (at 4:30 to $06: 30 \mathrm{am})$ and afternoon $(03: 00$ to $05: 00 \mathrm{pm})$ on each cattle. Measurements of milk yield were done using digital scales. Total milk yield was measured in kilograms. Sampling of $200 \mathrm{ml}$ milk on each dairy cattle was done after homogenizing milk in milking bucket which were analyzed using Milkotester. The measurement of milk quality includes fat, protein, lactose, solid non fat (SNF) and recorded in units of $\%$. Dry matter of milk is calculated by summing SNF with milk fat. Milk yield was corrected to $4 \%$ FCM $((0.4 \mathrm{x}$ milk yield $)+(15 \mathrm{x}$ milk yield $\mathrm{x}$ fat milk $))$ using the Gaines method [30].

The feed efficiency (milk production/dry matter intake) and Income Over Feed Cost (IOFC) ((the milk price $\mathrm{x}$ milk yield)/feed cost) were calculated according to the [13].

\subsection{Data Analysis}

Data were analyzed using t-test as independent samples [14].

\section{Results and Discussion}

\subsection{Dry Matter Intake (DMI)}

DMI of dairy cows showed significantly difference among treatment groups $(\mathrm{P}<0.01)$ (Table 3$)$. Dairy cows received T2 has higher DMI of forage rather than the other groups. However, DMI of T2 did not significantly different with T1, T4 and T7. Instead DMI concentrate of cows received T2 showed a lower value, but cow received T2 were not significantly different with cows received T7. Total DMI of cows received T3 is higher than others, but cows received T3 were not significantly different with cows received T4. DMI of feed influenced by the content of the feed in each treatment. This means that the content of the dry matter feed will determine the adequacy of nutrient in the body of cattle as well as affecting the type and number of the major metabolite produced in the rumen. [15] suggest that the nutrients provided in feed of dairy cows was converted to metabolites in the rumen such as acetic acid, butyric, propionic acid, glucose, free fatty acids, triacylglycerol, and amino acids for use in all body tissues.

DMI of feed in this study was lower than [16], 11.98-12.99 $\mathrm{kg} / \mathrm{h} / \mathrm{d}$; [5], 14.54-15.32 kg/h/d; [6], 15.25-15.88 kg/h/d; [7], $14.09-17.44 \mathrm{~kg} / \mathrm{h} / \mathrm{d} ;$ [17], 16.19-16.75 kg/h/d; [18], 18.7-20.3 $\mathrm{kg} / \mathrm{h} / \mathrm{d}$ and [19], 20.93-21.21 kg/h/d. Low consumption DMI of feed in the present study due to the low density of the feed caused by the provision of high fiber feed ingredient. [20] stated that the main factors affecting nutrient intake and rumen fulfillment in dairy cows is structural fiber content in the feed. If the feed consumed contains many structural fibers will cause the rate of feed in the rumen fermentation is slow so that the retention time of feed in the rumen becomes longer which in turn will reduce the intake of feed.

Differences in DMI of forage and concentrates affect the ratio of forage and concentrates. When viewed from the supply of nutrients in feed, the best ratio DMI of forage and concentrates in this study is shown by cows received T1. [4] states that the best ratio of DMI forage and concentrates is 50:50 because it provides a balance of nutrients in dairy cows. In this study, the ratio of DMI of forage and concentrates 25:75 showed the better rasio than 50:50; 62:38 and 64:36. The results were consistent with [21] who state increase in the ratio of forage and concentrates from 47:53 to $54: 45,61: 39$ and 68.32 did not affect the increase in DMI of feed. [10] stated that balance of protein and energy in early lactation dairy cows did not have an impact on 4\% FCM, fat, lactose, dry matter and solid non fat (SNF).

DMI of feed in this study ranged from 1.31-2.45\% body weight. This value is lower than the results [6], 2.99-3.19\%. In this study, cows received T3 and T4 has met the needs of dairy cows based on NRRDC [12]. Differences of DMI of feed in this study due to the differences in the formula feed and nutrient content in feed treatment. 


\section{International Journal of Science and Research (IJSR) \\ ISSN (Online): 2319-7064}

Index Copernicus Value (2015): 78.96 | Impact Factor (2015): 6.391

\subsection{Crude Protein Intake (CPI)}

CPI of dairy cows showed significantly difference among groups $(\mathrm{P}<0.01)$ (Table 4). Cows received T3 shows CPI of feed were higher than that of other groups. The high CPI of cows received $\mathrm{T} 3$ due to the high protein content of feedstuff.

The results of this study showed a lower than that of [16], $1.85-1.97 \mathrm{~kg} / \mathrm{h} / \mathrm{d}$ and [18], 3.17-3.76 kg/h/d. CPI of feed in this study can fullfill the $\mathrm{CP}$ requirement dairy cows according to NRRDC [12], except in group T7. Provision of concentrate feed were higher than forage in this study affect the CPI of lactation dairy cows in this study fulfilled based on NRRDC. The protein content of feed on the study well good enough so the protein requirement of lactating dairy cows were met.

\subsection{Total Digestible Nutrient (TDN)}

Total digestible nutrients (TDN) of dairy cows were showed significantly difference among groups $(\mathrm{P}<0.01)$ (Table 5). Cows in groups T3 consumed more TDN than other groups. However, cows in group T3 were not significantly different with cows in group T6. TDN intake differences in this study due to differences in TDN content of feedstuff on each treatment. TDN feed in this study ranged from $0.85-1.56 \%$ body weight. TDN requirement of dairy cows according to NRRDC [12] in Cibungbulang smallholder dairy farm were only fullfill in groups of T3, T5 and T6.

Table 3: Dry Matter Intake (DMI) of Each Treatment $(\mathrm{kg} / \mathrm{h} / \mathrm{d})$ on Cibungbulang Smallholder Dairy Farm

\begin{tabular}{|c|c|c|c|c|c|c|c|c|}
\hline Variable & $\mathrm{T} 1$ & $\mathrm{~T} 2$ & $\mathrm{~T} 3$ & $\mathrm{~T} 4$ & $\mathrm{~T} 5$ & $\mathrm{~T} 6$ & $\mathrm{~T} 7$ & $\mathrm{~T} 8$ \\
\hline Body weight $(\mathrm{kg})$ & 513.52 & 412.51 & 451.64 & 468.13 & 507.83 & 472.48 & 466.59 & 559.59 \\
\hline DMI of forage $(\mathrm{kg} / \mathrm{h} / \mathrm{d})$ & $3.98 \pm 0.30 \mathrm{c}$ & $4.3 \pm 1.85 \mathrm{c}$ & $2.80 \pm 0.30 \mathrm{a}$ & $4.02 \pm 0.29 \mathrm{c}$ & $3.47 \pm 0.24 \mathrm{~b}$ & $3.33 \pm 0.73 \mathrm{~b}$ & $3.77 \pm 0.04 \mathrm{c}$ & $3.08 \pm 0.13 \mathrm{ab}$ \\
\hline DMI of concentrate $(\mathrm{kg} / \mathrm{h} / \mathrm{d})$ & $4.02 \pm 0.31 \mathrm{~b}$ & $2.41 \pm 0.98 \mathrm{a}$ & $8.28 \pm 0.88 \mathrm{e}$ & $5.82 \pm 0.43 \mathrm{c}$ & $5.93 \pm 0.41 \mathrm{~cd}$ & $5.87 \pm 0.75 \mathrm{~cd}$ & $2.35 \pm 0.25 \mathrm{a}$ & $6.49 \pm 0.28 \mathrm{~d}$ \\
\hline $\begin{array}{c}\text { DMI of forage }: \text { concentrate } \\
\text { rasio }\end{array}$ & $50: 50$ & $64: 36$ & $25: 75$ & $41: 59$ & $37: 63$ & $36: 64$ & $62: 38$ & $32: 68$ \\
\hline Total DMI $(\mathrm{kg} / \mathrm{h} / \mathrm{d})$ & $8.00 \pm 0.61 \mathrm{~b}$ & $6.72 \pm 2.83 \mathrm{a}$ & $11.08 \pm 1.18 \mathrm{~d}$ & $9.84 \pm 0.72 \mathrm{~cd}$ & $9.40 \pm 0.66 \mathrm{c}$ & $9.20 \pm 1.18 \mathrm{bc}$ & $6.12 \pm 0.65 \mathrm{a}$ & $9.57 \pm 0.42 \mathrm{c}$ \\
\hline DMI/BW(\%) & 1.56 & 1.63 & 2.45 & 2.10 & 1.86 & 1.95 & 1.31 & 1.71 \\
\hline NRRDC $(\mathrm{kg} / \mathrm{h} / \mathrm{d})$ & 10.77 & 10.27 & 9.80 & 9.58 & 10.41 & 10.04 & 10.54 & 11.24 \\
\hline
\end{tabular}

A different superscript in the same row showed a high significantly difference $(\mathrm{P}<0.01)$;

BW, Body weight; DMI, Dry matter intake; NRRDC, Nutrient Requirement of Ruminan in Developing Countries;

Table 4: Crude Protein Intake (CPI) of Each Treatment $(\mathrm{kg} / \mathrm{h} / \mathrm{d})$ on Cibungbulang Smallholder Dairy Farm

\begin{tabular}{|l|c|c|c|c|c|c|c|c|}
\hline \multicolumn{1}{|c|}{ Variable } & $\mathrm{T} 1$ & $\mathrm{~T} 2$ & $\mathrm{~T} 3$ & $\mathrm{~T} 4$ & $\mathrm{~T} 5$ & $\mathrm{~T} 6$ & $\mathrm{~T}$ & $\mathrm{~T}$ \\
\hline \multirow{2}{*}{ CPI of forage $(\mathrm{kg} / \mathrm{h} / \mathrm{d})$} & $0.64 \pm$ & $0.52 \pm$ & $0.36 \pm$ & $0.46 \pm$ & $0.48 \pm$ & $0.33 \pm$ & $0.44 \pm$ & $0.51 \pm$ \\
& $0.05 \mathrm{~d}$ & $0.22 \mathrm{c}$ & $0.04 \mathrm{a}$ & $0.03 \mathrm{~b}$ & $0.03 \mathrm{bc}$ & $0.04 \mathrm{a}$ & $0.05 \mathrm{~b}$ & $0.02 \mathrm{c}$ \\
\hline \multirow{2}{*}{ CPI of concentrate $(\mathrm{kg} / \mathrm{h} / \mathrm{d})$} & $0.63 \pm$ & $0.41 \pm$ & $1.58 \pm$ & $1.02 \pm$ & $0.83 \pm$ & $1.00 \pm$ & $0.37 \pm$ & $0.60 \pm$ \\
& $0.05 \mathrm{~b}$ & $0.17 \mathrm{a}$ & $0.17 \mathrm{e}$ & $0.07 \mathrm{~d}$ & $0.06 \mathrm{c}$ & $0.13 \mathrm{~d}$ & $0.04 \mathrm{a}$ & $0.03 \mathrm{~b}$ \\
\hline \multirow{2}{*}{ CPI of feed $(\mathrm{kg} / \mathrm{h} / \mathrm{d})$} & $1.27 \pm$ & $0.93 \pm$ & $1.94 \pm$ & $1.48 \pm$ & $1.31 \pm$ & $1.34 \pm$ & $0.80 \pm$ & $1.11 \pm$ \\
& $0.10 \mathrm{c}$ & $0.39 \mathrm{a}$ & $0.21 \mathrm{e}$ & $0.10 \mathrm{~d}$ & $0.09 \mathrm{c}$ & $0.17 \mathrm{~cd}$ & $0.09 \mathrm{a}$ & $0.05 \mathrm{~b}$ \\
\hline CPI/BW $(\%)$ & 0.25 & 0.23 & 0.43 & 0.32 & 0.25 & 0.28 & 0.17 & 0.20 \\
\hline NRRDC $(\mathrm{kg} / \mathrm{h} / \mathrm{d})$ & 0.92 & 0.91 & 0.87 & 0.90 & 0.91 & 0.89 & 0.90 & 0.95 \\
\hline
\end{tabular}

A different superscript in the same row showed a high significantly difference $(\mathrm{P}<0.01)$;

BW, By weight; NRRDC, Nutrient Requirement of Ruminan in Developing Countries;

Table 5 : Total Digestible Nutrient (TDN) of Each Treatment $(\mathrm{kg} / \mathrm{h} / \mathrm{d})$ on Cibungbulang Smallholder Dairy Farm

\begin{tabular}{|l|r|r|r|r|r|r|r|r|}
\hline \multicolumn{1}{|c|}{ Variable } & \multicolumn{1}{c|}{$\mathrm{T} 1$} & \multicolumn{1}{c|}{$\mathrm{T} 2$} & \multicolumn{1}{c|}{$\mathrm{T} 3$} & $\mathrm{~T} 4$ & \multicolumn{1}{c|}{$\mathrm{T} 5$} & \multicolumn{1}{c|}{$\mathrm{T} 6$} & $\mathrm{~T} 7$ & $\mathrm{~T} 8$ \\
\hline TDN of forage $(\mathrm{kg} / \mathrm{h} / \mathrm{d})$ & $3.12 \pm$ & $3.13 \pm$ & $1.99 \pm$ & $2.25 \pm$ & $2.58 \pm$ & $2.59 \pm$ & $2.94 \pm$ & $2.42 \pm$ \\
& $0.24 \mathrm{e}$ & $1.34 \mathrm{ae}$ & $0.21 \mathrm{a}$ & $0.17 \mathrm{~b}$ & $0.18 \mathrm{c}$ & $0.33 \mathrm{~cd}$ & $0.31 \mathrm{de}$ & $0.11 \mathrm{bc}$ \\
\hline TDN of concentrate & $1,98 \pm$ & $1.31 \pm$ & $5.05 \pm$ & $3.26 \pm$ & $3.38 \pm$ & $3.84 \pm$ & $1.49 \pm$ & $3.04 \pm$ \\
(kg/h/d) & $0.15 \mathrm{~b}$ & $0.54 \mathrm{a}$ & $0.54 \mathrm{~d}$ & $0.24 \mathrm{c}$ & $0.24 \mathrm{c}$ & $0.49 \mathrm{c}$ & $0.16 \mathrm{a}$ & $0.14 \mathrm{~cd}$ \\
\hline TDN of feed $(\mathrm{kg} / \mathrm{h} / \mathrm{d})$ & $5.10 \pm$ & $4.44 \pm$ & $7.03 \pm$ & $5.51 \pm$ & $5.96 \pm$ & $6.43 \pm$ & $4.43 \pm$ & $5.66 \pm$ \\
& $0.39 \mathrm{bc}$ & $1.87 \mathrm{ab}$ & $0.75 \mathrm{e}$ & $0.40 \mathrm{~cd}$ & $0.42 \mathrm{~d}$ & $0.82 \mathrm{de}$ & $0.47 \mathrm{a}$ & $0.25 \mathrm{~d}$ \\
\hline TDN/BW $(\%)$ & 0.99 & 1.08 & 1.56 & 1.18 & 1.16 & 1.28 & 0.85 & 1.01 \\
\hline NRRDC $(\mathrm{kg} / \mathrm{h} / \mathrm{d})$ & 5.91 & 5.47 & 5.49 & 5.71 & 5.75 & 5.60 & 5.80 & 6.08 \\
\hline
\end{tabular}

A different superscript in the same row showed a high significantly difference $(\mathrm{P}<0.01)$;

BW, Body weight; NRRDC, Nutrient Requirement of Ruminan in Developing Countries;

\subsection{Milk Yield and composition}

Milk yield $(\mathrm{kg} / \mathrm{h} / \mathrm{d})$ of dairy cows on Cibungbulang showed significantly difference among groups $(\mathrm{P}<0.01)$ (Table 6). The highest milk yield showed on cows in T8. However cows in T8 were not significantly different with cows in T3. Milk yield in this study was lower than [17], 17.41-26.43 kg/d and [19], 30.18-31.90 kg/d. The differences of milk yield in this study due to differences DMI of feed and nutrient content of each treatment. Milk yield in this study positively correlated with DMI $(\mathrm{Y}=1,203+1,064 \mathrm{x}) ; \mathrm{R}=0.408) ; \mathrm{CPI}(\mathrm{Y}=$ $4,555+4.677 \mathrm{x} ; \mathrm{R}=0365)$ and $\mathrm{TDN}$ intake $(\mathrm{Y}=2,513+$ $1,427 \mathrm{x} ; \mathrm{R}=0327)$. DMI of feed determines the amount of available nutrients for basic living and production [16]. [15] stated that the nutrients provided in the feed is converted to metabolites in the rumen and used for energy, glycogen, 


\section{International Journal of Science and Research (IJSR) \\ ISSN (Online): 2319-7064 \\ Index Copernicus Value (2015): 78.96 | Impact Factor (2015): 6.391}

synthesis triasilgliseride, synthesis of fatty acids and synthesis of amino acids in various body tissues of cattle. In lactating dairy cows, the primary metabolite is used for the synthesis of milk. The milk yield depends on the supply of nutrients [22].

Differences in 4\% FCM caused by DMI of feed and fat content in milk. [23] stated that the increase in the total DMI of feed strongly influenced by milk yield and milk composition up to $15-20 \mathrm{~kg} / \mathrm{d}$. [24] states that the average milk yield of dairy cows in Indonesia is $15 \mathrm{~L} / \mathrm{h} / \mathrm{d}$ or equivalent $15.42 \mathrm{~kg} / \mathrm{h} / \mathrm{d}$.

Production of fat, protein, lactose, SNF and DM of milk $(\mathrm{kg} / \mathrm{h} / \mathrm{d})$ showed a high significantly difference $(\mathrm{P}<0.01)$.
Milk fat Production at cows received T8 higher than others. However, cows received T8 were not significantly different with cows received T3. Milk fat production were influenced by the milk yield and milk fat content. The fat content of milk in this study is higher (3.28-4.13\%) than [19], 3.40-3.57\% and lower than [17], 3.71-4.26\%. [25] states that the ratio of forage and concentrates affect the fat content of milk. Most of the milk fat is formed of triglycerides (97-98\%) and only a small portion formed of phospholipid $(2-3 \%)$. The main precursor of milk fat were glucose, acetate, $\beta$-hydroxybutyric acid, triglycerides and lower lipoproteins from blood. Source of milk fatty acid formation are glucose, triacylglycerol from food or formed by rumen bacteria and fatty acids were synthesized in the udder gland [26].

Table 6 : Milk Yield and Composition $(\mathrm{kg} / \mathrm{h} / \mathrm{d})$ of Each Treatment on Cibungbulang Smallholder Dairy Farm.

\begin{tabular}{|l|r|r|r|r|r|r|r|r|}
\hline \multicolumn{1}{|c|}{ Variable } & \multicolumn{1}{c|}{ T1 } & \multicolumn{1}{c|}{ T2 } & \multicolumn{1}{c|}{ T3 } & \multicolumn{1}{c|}{ T4 } & \multicolumn{1}{c|}{ T5 } & \multicolumn{1}{c|}{ T6 } & \multicolumn{1}{c|}{ T7 } \\
\hline Milk yield (kg/h/d) & $11.64 \pm$ & $6.19 \pm$ & $13.74 \pm$ & $10.60 \pm$ & $9.37 \pm$ & $10.01 \pm$ & $7.62 \pm$ & $16.27 \pm$ \\
& $3.12 \mathrm{bc}$ & $1.76 \mathrm{a}$ & $4.91 \mathrm{~cd}$ & $4.31 \mathrm{abc}$ & $3.60 \mathrm{abc}$ & $4.28 \mathrm{abc}$ & $3.51 \mathrm{ab}$ & $0.46 \mathrm{~d}$ \\
\hline Milk yield 4\% FCM & $11.52 \pm$ & $6.83 \pm$ & $12.89 \pm$ & $10.63 \pm$ & $9.23 \pm$ & $10.33 \pm$ & $6.95 \pm$ & $16.52 \pm$ \\
(kg/h/d) & $2.68 \mathrm{~b}$ & $2.21 \mathrm{a}$ & $4.08 \mathrm{bc}$ & $3.98 \mathrm{ab}$ & $3.47 \mathrm{ab}$ & $3.80 \mathrm{ab}$ & $3.12 \mathrm{a}$ & $2.18 \mathrm{c}$ \\
\hline Fat $(\mathrm{kg} / \mathrm{h} / \mathrm{d})$ & $0.46 \pm$ & $0.29 \pm$ & $0.49 \pm$ & $0.43 \pm$ & $0.37 \pm$ & $0.42 \pm$ & $0.26 \pm$ & $0.67 \pm$ \\
& $0.10 \mathrm{~b}$ & $0.10 \mathrm{ab}$ & $0.15 \mathrm{bc}$ & $0.16 \mathrm{ab}$ & $0.14 \mathrm{ab}$ & $0.14 \mathrm{ab}$ & $0.12 \mathrm{a}$ & $0.08 \mathrm{c}$ \\
\hline Protein $(\mathrm{kg} / \mathrm{h} / \mathrm{d})$ & $0.36 \pm$ & $0.18 \pm$ & $0.4 \pm$ & $0.32 \pm$ & $0.30 \pm$ & $0.86 \pm$ & $0.23 \pm$ & $0.51 \pm$ \\
& $0.09 \mathrm{~b}$ & $0.05 \mathrm{a}$ & $0.15 \mathrm{bc}$ & $0.13 \mathrm{ab}$ & $0.11 \mathrm{ab}$ & $0.14 \mathrm{~d}$ & $0.10 \mathrm{ab}$ & $0.07 \mathrm{c}$ \\
\hline Lactose $(\mathrm{kg} / \mathrm{h} / \mathrm{d})$ & $0.54 \pm$ & $0.27 \pm$ & $0.61 \pm$ & $0.47 \pm$ & $0.44 \pm$ & $0.31 \pm$ & $0.36 \pm$ & $0.76 \pm$ \\
& $0.13 \mathrm{~b}$ & $0.08 \mathrm{a}$ & $0.22 \mathrm{bc}$ & $0.20 \mathrm{ab}$ & $0.16 \mathrm{ab}$ & $0.21 \mathrm{ab}$ & $0.14 \mathrm{ab}$ & $0.11 \mathrm{c}$ \\
\hline SNF $(\mathrm{kg} / \mathrm{h} / \mathrm{d})$ & $1.00 \pm$ & $0.51 \pm$ & $1.14 \pm$ & $0.89 \pm$ & $0.83 \pm$ & $0.46 \pm$ & $0.65 \pm$ & $1.42 \pm$ \\
& $0.25 \mathrm{a}$ & $0.15 \mathrm{a}$ & $0.40 \mathrm{ab}$ & $0.37 \mathrm{a}$ & $0.29 \mathrm{a}$ & $0.38 \mathrm{a}$ & $0.27 \mathrm{a}$ & $0.20 \mathrm{~b}$ \\
\hline DM (kg/h/d) & $1.46 \pm$ & $0.80 \pm$ & $1.63 \pm$ & $1.32 \pm$ & $1.19 \pm$ & $1.28 \pm$ & $0.91 \pm$ & $2.08 \pm$ \\
& $0.34 \mathrm{c}$ & $0.25 \mathrm{a}$ & $0.54 \mathrm{c}$ & $0.52 \mathrm{bc}$ & $0.42 \mathrm{ab}$ & $0.51 \mathrm{bc}$ & $0.38 \mathrm{ab}$ & $0.28 \mathrm{~d}$ \\
\hline
\end{tabular}

A different superscript in the same row showed a high significantly difference $(\mathrm{P}<0.01)$;

FCM, Fat Corrected Milk; SNF, Solid non fat; DM, Dry Matter

Protein production of cows in T6 were higher than others. Production of milk proteins is influenced by the milk yield and milk protein content. There were no differences in levels of milk protein of this study $(3.03-3.17 \%)$ with [17], 3.00$3.20 \%$. However, the protein content of milk in this study was lower than [19], 3.22-3.27\%. [26] suggest that protein feed were hydrolyzed into peptides and amino acids by rumen microorganisms and some amino acids will be formed into organic acids, ammonia and Carbondioksida. Amino acids used for protein synthesis or into the systemic blood and join the catabolism of amino acids of tissue then used for protein synthesis by the body tissue [15]. In lactating dairy cows, the amino acids used for synthesis protein milk.

Lactose production at cows in $\mathrm{T} 8$ higher than other groups. However cows in $\mathrm{T} 8$ were not significantly different with cows in T3. Lactose milk production is affected by the milk yield and lactose content of milk. Lactose content of milk in this study (4.56-4.81\%) did not different with [19], 4.47$4.51 \%$. [26] states that largely, the lactose in milk derived from glucose and galactose were absorbed by the cells secretions of blood. Lactose milk is a milk carbohydrates, synthesized in the udder gland. Precursor of lactose milk is blood glucose, reaching $80 \%$. Lactose content of milk is relatively fixed, but production of lactosa increases as the increase in milk yield. Fluctuations of lactose content in accordance with the dynamics of milk yield during lactation. [21] states the ratio of forage and concentrates affect the content of fat, protein, lactose and SNF of milk.

\subsection{Feed Efficiency and Income Over Feed Cost (IOFC)}

Feed efficiency in this study showed significantly difference among groups $(\mathrm{P}<0.01) \quad($ Table 7$)$. Feed efficiency in this study (0.12-0.22) was lower than [6], 1.07-1.16 and [13], 1.51. Value of feed efficiency in this study illustrate that the feed were used inefficient to increase milk yield due to the amount of feed were higher to produce $1 \mathrm{~kg}$ of milk. The use nutrients efficiently will prevent deficiency or excess intake of nutrients. Deficiency nutrition can limit production and animal health worsen, while excess intake of nutrients at high levels cause poisoning or animal health exacerbates. [27] states that feed efficiency in dairy cows production is an important factor that must be considered. If the nutrients consumed did not converted into the milk, food reserves of the body, or to the development of fetal, nutrients will be excreted into the environment, resulting in emissions, such as ammonia, methane or nitrous oxide [28].

Value income over feed cost showed a high significantly difference $(\mathrm{P}<0.01)$ (Table 7). Income over feed cost in this study (1.65-2.80) higher than the normal range. [29] states that the normal range of income over feed cost is $>1.4$. This means economically, all pattern of feed given were efficient. The best income over feed cost shown at cows received T8. However cows received T8 did not significantly different

\section{Volume 6 Issue 7, July 2017 www.ijsr.net}




\section{International Journal of Science and Research (IJSR) \\ ISSN (Online): 2319-7064}

Index Copernicus Value (2015): 78.96 Impact Factor (2015): 6.391

with cows received $\mathrm{T} 1, \mathrm{~T} 3, \mathrm{~T} 4, \mathrm{~T} 5$ and $\mathrm{T} 7$.

Table 7 : Feed Efficiency of Each Treatment $(\mathrm{kg} / \mathrm{h} / \mathrm{d})$ on Cibungbulang Smallholder Dairy Farm

\begin{tabular}{|l|c|c|c|c|c|c|c|c|}
\hline \multicolumn{1}{|c|}{ Variable } & $\mathrm{T} 1$ & $\mathrm{~T} 2$ & $\mathrm{~T} 3$ & $\mathrm{~T} 4$ & $\mathrm{~T} 5$ & $\mathrm{~T} 6$ & $\mathrm{~T} 7$ & $\mathrm{~T} 8$ \\
\hline Feed efficiency & $0.17 \pm$ & $0.11 \pm$ & $0.13 \pm$ & $0.11 \pm$ & $0.13 \pm$ & $0.14 \pm$ & $0.14 \pm$ & $0.18 \pm$ \\
& $0.04 \mathrm{bc}$ & $0.05 \mathrm{a}$ & $0.04 \mathrm{ab}$ & $0.03 \mathrm{ab}$ & $0.06 \mathrm{ab}$ & $0.04 \mathrm{ab}$ & $0.08 \mathrm{abc}$ & $0.03 \mathrm{c}$ \\
\hline Income Over Feed Cost & $2.42 \pm$ & $1.65 \pm$ & $1.88 \pm$ & $2.00 \pm$ & $1.83 \pm$ & $1.70 \pm$ & $2.49 \pm$ & $2.80 \pm$ \\
(IOFC) & $0.65 \mathrm{ab}$ & $0.47 \mathrm{a}$ & $0.67 \mathrm{ab}$ & $0.66 \mathrm{ab}$ & $0.84 \mathrm{ab}$ & $0.61 \mathrm{a}$ & $1.40 \mathrm{ab}$ & $0.42 \mathrm{~b}$ \\
\hline Price of feed (IDR) & 24469.22 & 19036.42 & 37528.29 & 27003.61 & 26091.00 & 29884.99 & 15591.32 & 29583.50 \\
\hline
\end{tabular}

A different superscript in the same row showed a high significantly difference $(\mathrm{P}<0.01)$;

Cows in T3 showed higher feed prices i.e., IDR 37258.29 and cows in T7 indicate lower prices i.e., IDR 15591.32. The price of feed in this study was higher than [6], IDR 1963.32510,3 and [8], IDR 18803-22229.84. The analysis showed that the price of feed to produce $1 \mathrm{~kg}$ of milk will affect the cost of production on a dairy farm. This means that the cost of feed used for milk yield would reduce the cost of production and the dairy business will affect the level income of farmers. [13] states that dairy cows how efficiently convert feed into milk can affect farm operations. This means that the use of feed at a low price and good quality will affect profit or loss of the dairy business.

\section{Conclusion}

The pattern of feeding on Cibungbulang smallholder dairy farm varied so the milk yield also varies. Best feed formula given by cows received T3 $(38.18 \%$ tofu waste $+16.50 \%$ soybean hulls $+8.86 \%$ straw) with a better DMI, CPI and TDN for optimal milk yield and the best IOFC.

\section{Acknowledgments}

We thanks to Chairman of farmers in Cibungbulang Smallholder Dairy Farm for technical support throughout this study. This study was funded by Direktorat Jenderal Pendidikan Tinggi through Beasiswa Pendidikan Pascasarjana (BPPS) tahun Anggaran 2015, grant no : 2604/E4.4/2012 and Faculty of Animal Science Universitas Halu Oleo through "Hibah Doktor Fakultas Peternakan UHO tahun 2015".

\section{References}

[1] Anggraeni, S.A., E. Kurnianto, S. Johari, Sutopo and Z Shujun, "Milk production and reproductive trait caused by LOC514211 gene mutation in dairy cows", J. Indonesian Trop. Anim. Agric, 40(4) : 191-198, 2015.

[2] Atabany, A., B.P. Purwanto, T. Toharmat and A. Anggraeni, "Hubungan masa kosong dengan produktivitas pada sapi perah Friesian Holstein di Baturraden, Indonesia", Med. Pet, 34(2):77-82, 2011.

[3] Despal, D., I.G. Permana, S.N. Safarina and A.J. Tatra, " Penggunaan berbagai sumber karbohidrat terlarut air untuk meningkatkan kualitas silase daun rami," Med. Pet, 34(1):69-76, 2011.

[4] Musnandar, E, "Efisiensi energi pada sapi perah holstein yang diberi berbagai imbangan rumput dan konsentrat. Jurnal Penelitian Universitas Jambi", Seri Sains, 13 (2):53-58, 2011.
[5] Zahera, R., I.G. Permana and D. Despal, "Utilization of mungbean's green house fodder and silage in the ration for lactating dairy cows", Med. Pet, 38(2):123-131, 2015.

[6] Lestari, D.A., L. Abdullah and D. Despal, "Comparative study of milk production and feed efficiency based on farmers best practices and National Research Council", Med. Pet, 38(2):110-117, 2015.

[7] Astuti, A., A. Agus and S.P.S. Budhi, "Pengaruh penggunaan high quality feed supplement terhadap konsumsi dan kecernaan nutrien sapi perah awal laktasi", Buletin Peternakan, 33(2), 2009.

[8] Eddy, B.T., W. Roessali and S. Marzuki, " Dairy cattle farmers behaviour and factors affecting the effort to enhance the economic of scale at Getasan District, Semarang Regency", J. Indonesian Trop. Anim. Agric, 37(1):34-40, 2012.

[9] Widiati R., Adiarto and B.S. Hertanto, "Profitability of smallholder dairy farm based on the performance of lactating cows and fresh milk market price at lowland areas of Yogyakarta", J.Indonesian Trop.Anim.Agric, 37(2):132-138, 2012.

[10]Widyobroto, W.P., R. Rochijan, I. Ismaya, A. Adiarto and Y.Y. Suranindyah, "The impact of balanced energy and protein supplementation to milk production and quality in early lactating dairy cows", J.Indonesian Trop. Anim. Agric, 41(2)(2): 83-90, 2016.

[11]AOAC, official methods of Analysis, 17th ed, Association of Official Analytical Chemists, Washingon DC, USA, 2005.

[12]Kearl L.C, "Nutrien requirements of ruminants in developing countries. International feedstuffs intitute utah agriculture experiment station", Utah State University, Logan Utah, 1982.

[13]Casper, D.P, "Factors affecting feed efficiency of dairy cows", Tri-State Dairy Nutrition Conference, 133-144, 2008.

[14]Setiawan, B, "Teknik praktis analisis data penelitian dan bisnis dengan SPSS", Penerbit Andi, Yogyakarta, 2015.

[15]McDonald., R.A. Edward, J.F.D. Greenhalgh and C.A. Morgan, "Animal nutrition ed 5", New York : John Willey and Sons Inc (Copublished), 1995.

[16]Nugroho, H.D., I.G. Permana and D. Despal, "Utilization of bioslurry on maize hydroponic fodder as a corn silage supplement on nutrient digestibility and milk production of dairy cows", Med. Pet, 38(1):70-76, 2015.

[17]Liu, S., R. Zhang, R. Kang, J. Meng and C. Ao, "Milk fatty acids profiles and milk production from dairy cows fed different forage quality diets", J. Anim. Nutr, 2(4):329-333, 2016.

\section{Volume 6 Issue 7, July 2017 www.ijsr.net}


[18]Puhakka, L., S. Jaakkola, I. Simpura, T. Kokkonen and A. Vanhatalo, "Effects of replacing rapeseed meal with fava bean at 2 concentrate crude protein levels on feed intake, nutrient digestion, and milk production in cows fed grass silage-based diets", J. Dairy Sci, 99(10):79938006, 2016.

[19]Whelan, S.J., W. Carey, T.M. Boland, M.B. Lynch, A.K. Kelly, G. Rajauria and K.M. Pierce, "The effect of by-product inclusion level on milk production, nutrient digestibility and excretion, and rumen fermentation parameters in lactating dairy cows offered a pasturebased diet", J Dairy Sci, 100:1-8, 2016.

[20]Kendall, C., C. Leonard, O.C. Hoffman, and D.K. Association, "Intake and milk production of cows fed diets that differed in dietary neutral detergent fiber and neutral detergent fiber digestibility", J. Dairy Sci, 92:313-323, 2009.

[21]Aguerre, M.J., M.A. Wattiaux, J.M. Powell, G.A. Broderick and C. Arndt, "Effect of forage-toconcentrate ratio in dairy cow diets on emission of methane, carbon dioxide, and ammonia, lactation performance, and manure excretion", J. Dairy Sci, 94(6):3081-3093, 2011.

[22]Min, B.R., S.P. Hart, T. Sahlu and L.D. Satter, "The effect of diets on milk production and composition, and on lactation curves in pastured dairy goats", J. Dairy Sci, 88 (7):2604-2615, 2005.

[23]Saijpaul, S., R.S. Grewal, R. Kaur and P.K. Naik, "Evaluation of some potential complete rations evaluation of some potential complete rations economic milk production in crossbred cows", Animal Nutrition and Feed Technology, 5:203-210, 2005.

[24]Kusnadi, U and E. Juarini, "Optimalisasi pendapatan usaha pemeliharaan sapi perah dalam upaya peningkatan produksi susu nasional', Wartazoa, 17 (1):21-28, 2007.

[25]Sterk, A., B.E. Johansson, H.Z. Taweel, M. Murphy, A.M. van Vuuren, W.H. Hendriks and J. Dijkstra, "Effects of forage type, forage to concentrate ratio, and crushed linseed supplementation on milk fatty acid profile in lactating dairy cows", J. Dairy Sci, 94(12):6078-6091, 2011.

[26]Larson. B.L, "Biosynthesis and cellular secretion of milk", Ames : Iowa State University Press, 1981.

[27]Phuong, H. N., N. C. Friggens, I. J. M. De Boer, \& P. Schmidely, "Factors affecting energy and nitrogen efficiency of dairy cows: A meta-analysis", J. Dairy Sci, 96:7245-7259, 2013.

[28]Thomassen, M.A., M.A. Dolman, K.J. Van Calker and I.J.M. De Boer, "Relating life cycle assessment indicators to gross value added for Dutch dairy farms", Ecol Econ, 68:278-2009.

[29]Linn, J, "Feed Efficiency: Its economic impact in lactating dairy cows", WCDS Advances in Dairy Technology, 18:19-28, 2006.

[30]Wickes, R.B, "Feeding experiment with dairy cattle. In. dairy cattle research techniques", Ternouth $\mathrm{JH}$, editor, Australia (AU): Queensland of Primary Industries, 1983. 